SERGEI PODBOLOTOV (Ankara, Turkey)

\title{
MONARCHISTS AGAINST THEIR MONARCH: THE RIGHTISTS' CRITICISM OF TSAR NICHOLAS II
}

In turbulent 1905, when the revolution shook the traditional pillars of the Russian autocracy, Nicholas II called his loyal subjects to rally around the throne and to help in the struggle with the rebels. Those responded formed the Right (pravoe) movement. It turned out to be extremely divergent. The idea to save the autocracy as a Russian national foundation attracted oldfashioned intellectuals - Slavophiles and high-ranked bureaucrats, peasants seeking patronage of the tsar and rich gentry, nationalistic populists and police officers. The Union of Russian People (SRN) headed by A. I. Dubrovin became the main party of the extreme Rightists or the Black Hundreds. It suffered two major splits, and as a result somewhat less extreme parties - the Union of the Archangel Michael (SMA) of V. M. Purishkevich and the "renovated" SRN of N. E. Markov came into being.' The major party of the moderate right wing, the All-Russian National Union (the VNS, or the Nationalists), where V. V. Shul'gin became the most remarkable figure, emerged in the Third Duma period to support Stolypin and his reforms. ${ }^{2}$ Traditional Slavophiles like Lev Tikhomirov or General Alexander Kireev hated party politics and preferred to stay outside the party organizations. Yet they clearly belonged to the same political camp as convinced monarchists who strongly opposed constitutionalism and were sympathetic to the Right. Despite their divergent backgrounds and views, many Rightists from various groups displayed one surprising common feature which historians have almost completely overlooked and which will be discussed in this article: hidden or open criticism of Tsar Nicholas II.

In accordance with the main party doctrine of autocracy, the emphasized declaration of loyalty and faithfulness to Nicholas II was the distinguishing

1. For the Union of the Russian People, see: Hans Rogger, Jewish Policies and Right-Wing Politics in Imperial Russia (London: Macmillan, 1986); Don Rawson, Russian Rightists and the Revolution of 1905 (Cambridge: Cambridge Univ. Press, 1995); S.A. Stepanov, Chernaia sotnia $v$ Rossii (Moscow: Nauka, 1992).

2. A recent monograph about the Nationalists is D. A. Kotsiubinskii, Russkii natsionalizm v nachale XX stoletiia. Rozhdenie $i$ gibel' ideologii Vserossiiskogo Natsional'nogo Soiuza (Moscow: ROSSPEN, 2001). 
mark of the Right. They sprinkled their numerous petitions to the tsar with expressions of "truly faithful feelings"; "in the name of the people" deputations of the supporters of autocracy presented themselves to Nicholas II; the right wing declared war on all genuine or imagined enemies of the tsar. Among the extreme Rightists the cult of the autocrat took on excessive and often pseudo-religious forms: the tsar was compared with "the sun that warmed the just and the guilty"; he was called "our only support at present and our bright happiness in the future", "all hopes" were pinned only on him; his words on autocracy were the motto of the movement; tsarist portraits were venerated like boly relics. ${ }^{3}$ This last trait moved Nicholas II; with pleasure he presented his pictures to his favorite, and, as he believed, the most loyal subjects. ${ }^{4}$

However, the other side of the coin of this monarchist movement was that its target in the circumstances of the worsening crises of the autocracy could be Nicholas II himself. This movement considered that the autocratic order was the most ideal for the country, but reality testified appallingly to the national crisis. Correspondingly, responsibility for such a state of political affairs had to lie inevitably not with objective shortcomings of the system but rather with the character of the reigning tsar himself.

The method of pointing out scapegoats - Jews, students, bureaucrats - was suitable for public propaganda especially among the lower classes. By contrast, in private conversations of the right-wing elite, Nicholas II himself was subjected to sharp and often well-grounded accusations. Disseminating critical views of the tsar could be risky because of the police repression; however, to have one's personal opinion in tsarist Russia (unlike in the Soviet Union) was not too dangerous.

For revolutionaries it was not particularly important who was sitting on the throne. From their point of view the Russian system was by definition

3. Pravye partii. Dokumenty i materialy (Moscow: ROSSPEN, 1998), 1: 600; Russkoe Znamia, March 17, 1907; Tretii Vserossiiskii s'"ezd russkikh liudei v Kieve (Kiev: Tip. T-va 1. N. Kushnereva, 1906) 65; Heinz-Dietrich Lowe, "Political Symbols and Rituals of the Russian Radical Right, 1900-1914," The Slavonic and East European Review, 76, no. 3 (July 1998), 456, 459-61.

4. Among recipients of a tsarist portrait signed by the tsar himself were various cells of the SRN, the oldest Rightist organization Russkoe Sobranie (Russian Assembly), the Russian Monarchist Party from Moscow, the Monarchist Congress of 1909, and personally Purishkevich, Shul'gin, the infamous leader of Odessa Black Hundreds A. I. Konovnitsyn, the editor of the Rightist magazine Grazhdanin V. P. Meshcherskii (Lowe, "Political Symbols and Rituals of the Russian Radical Right, 1906-1914," 459; Pravye partii, 1: 463; (Moscow, 1998), 2: 167, 534; Sovremennik, "Nikolai II," Rasoblacheniia (Berlin 1909), 266; Gosudarstvennyi Arkhiv Rossiiskoi Federatsii (GARF), f. 601, op. 2, d. 68; op. 1, d. 1288, 1. 5; W. E. Mosse, "Imperial Favourite V. P. Meshchersky and 'Grazhdanin'," The Slavonic and East European Review, 59, no. 4 (1981), 530 . 
headed by a tyrant, an oppressor of the people, a grand reactionary landlord. By contrast, the emperor as an individual played an enormously important role in the eyes of the monarchists. The main quality of the "ideal" autocrat was thought to be a clear consistent resolute will, which forced subjects to follow the political course defined from above and was insusceptible to passing political influences and selfish interests. Only then could one speak of an autocracy as a political practice. Nicholas II, because of his personal qualities, was completely unsuitable for this ideal monarchical role. The objective circumstances of the epoch, which prevented Nicholas II from reigning "autocratically," were not really taken into account by conservatives.

General Kireev, knowing well the ruling elite, sounded the alarm already in the early years of the reign of the last tsar. "The country is heading toward a constitution," the General foresaw in September 1900. "Our Polizei-Staat is becoming more and more impossible. It is bearable when in the hands of Frederick the Great or Catherine the Great, but not when the monarchy is divided among ministers, when it is divided into small change." The inability of Nicholas II to control the ministers was clear to Kireev: "There is no government! There are ministers who in their meetings with the tsar can achieve all they want to! Uncontrollable!"6 Under Nicholas II, Kireev wrote in his diary, the country was in an absurd situation, the worst imaginable: "There is autocracy but no autocrat." It was intolerable for a true monarchist: "What a situation! We are ruled by a pederast and a magician, Meshcherskii and Mssr. Filipp." (Homosexual Meshcherskii, the editor of Grazhdanin, was an influential unofficial adviser of the emperor, especially from the late 1890 s to 1903, and in 1909-1914, Filipp - French hypnotist who in 1901 became a personal friend of the tsarist couple.)

Monarchists' attempts to influence Nicholas II ran into the tsar's apparent lack of initiative and indifference, attributes totally unsuitable for an autocrat. The famous priest Ioann of Kronstadt, who sympathized with the Right, entered a very indicative prayer in his diary: "May the sleeping tsar awaken who has not /wielded his authority. ..."

Since it was clear that by the whim of fate an inappropriate figure was occupying the position of emperor, there was talk of a palace coup among highranked conservatives. However, there was no appropriate replacement for the

5. Rossiiskaia Gosudarstvennaia Biblioteka. Otdel Rukopisei (RGB OR), f. 126, d. 13 (Diary of A. A. Kireev, 1900-1904), 1. 50 (ob).

6. Ibid., 1. 81, 125 (Entries from April 1901 and February 1902).

7. Ibid., 1. 131 (Entry from March 1902). Emphasis in original.

8. Ibid., l. 52 (01)), 171 (ob) (Entries from October 1900 and September 1902).

9. Cited in S. L. Firsov, Pravoslavnaia Tserkov' $i$ gosudarstvo v poslednee desiatiletie sushchestvovaniia samoderzhaviia v Rossii (St. Petersburg: Izd-vo Russkogo Khristianskogo Gumanitarnogo universiteta, 1996), 129. 
current tsar. Mikhail Aleksandrovich, according to General Kireev, was "marvellous, moral," but "not bright, and, most importantly, had no desire to reign." Just as with his reigning older brother, Mikhail did not have qualities "necessary for an autocrat . . individual initiative, will. ..."10 A. V. Bordanovicha, a wife of a devoted popularizer of monarchy among the lower classes General E. V. Bogdanovich and a host of St. Petersburg aristocratic salons, had an even lower opinion of Mikhail: ". . . weakwilled, of limited intelligence, in the hands of the Jewess Vul'fart and, like the young tsarina, terrible for Russia." "The first and second [Princes] Vladimirovichs are both inveterate good-for-nothings," Kireev similarly considered other possible pretenders to the throne among the Romanovs. ${ }^{12}$

It is not surprising that, after the defeats in the Russo-Japanese War (arising from, as Kireev put it, "the Tsar's childish desire to conquer Manchuria" $^{13}$ ) and the start of the revolution, criticism of the unsuccessful ruler strengthened. Among the sharper critics was B. V. Nikol'skii, who became one of the leaders of the SRN and who at a personal audience with the emperor had made an extremely positive impression on Nicholas II for his thoughts about the necessity of the autocracy in Russia. ${ }^{14}$ However, secretly from the tsar, he was also thinking that under this autocrat to be a conservative one had to be radical and even revolutionary. ${ }^{15}$ His diary confirms that he was ready to go far: "Let you in on a secret? I think that it is naturally impossible to bring the tsar to his senses. He is worse than inept! He is - God forgive me - a total nobody! If so, then his reign will not be redeemed before long. Oh Lord, did we really deserve that our faith was so in vain? One assassination is now too little to clear the air. We need something Serbian." this Nikol'skii referred to a plot by the officers of a Belgrade garrison against the Serbian king Alexander I and his wife, both of whom they killed.) In a conversation with the Bogdanoviches, when discussing the catastrophic defeat at the Tsushima Straits, Nikol'skii argued that it was necessary "to change the dynasty" since it was impossible "to bring the stupid, inept, ignorant, pathetic person," the reigning emperor, "to his senses." "Yet if it were possible to hope for his suicide - that would be a chance. But he will never be

10. RGB OR, f. 126, d. 13 (Diary of A. A. Kireev. 1900-1904), 1. 198 (ob), 217 (Entries from January and March 1903).

11. A. V. Bogdanovich, Tri poslednikh samoderzhtsa (Moscow: Novosti, 1990), 493.

12. RGB OR, f. 126, d. 13 (Diary of A. A. Kireev. 1900-1904), 1. 198 (ob).

13. Bbid., 1. 222.

14. B. V. Anan'ich, R. Sh. Ganelin, eds., Nikolai II. Vospominaniia. Dnevniki (St. Petersburg: D. Bulanin, 1994), 74-75.

15. Rogger, Jewish Policies and Right Wing Politics in Imperial Russia, 214.

16. B. V. Nikol'skii, "Iz dnevnikov 1905 g.," in Nikolai II. Vospominaniia. Dnevniki , 77. 
able to do it!"17 Tikhomirov believed that with such a tsar as Nicholas, the autocratic course was doomed. Reading the reports about the tsarist receptions, Tikhomirov concluded that the Sovereign was extremely inconsistent. To some deputations the tsar said one thing, to others something surprisingly different. $^{18}$ The tsar's liberal steps made early in the revolution to pacify the opposition brought out extreme bewilderment among right-wing extremists. Some said that with the $u k a z$ of April 17, 1905 on religious freedom Nicholas II had "betrayed Orthodoxy." 19 The extreme Rightists could never reconcile themselves to the Manifesto of October 17 which limited the autocracy. Hans Rogger especially noted the persistent rumors that Rightists hated Nicholas II more than the Left and wanted to get rid of him. ${ }^{20}$ However, this kind of plan did not develop further than salon conversation.

After the October Manifesto, an epoch of public politics began, and a wide mass - or, as the conservative elite arrogantly put it, the "street" - was drawn into the rightist movement. Public debate within parties on the figure of the ruling tsar, similar to those in private (like that of Nikol'skii in the salon of Bogdanovich) or the circulation of critical notes left by conservatives in their diaries, were not permissible. The popular propaganda of Pravye parties never personally attacked Nicholas II - this was a serious taboo, not merely stimulated by fear of police repression. Orthodox monarchical doctrine emphasised that the tsar's mistakes would be smoothed over by the trust and obedience of the people. "If the people obey, then even if the tsar makes a mistake, then this is nothing particularly bad," wrote Tikhomirov. ${ }^{21}$ The autocrat was to be infallible in the eyes of the people (even if this contradicted reality), otherwise a bunt (mutiny) might result. The program of Russkoe Sobranie specially highlighted this: "The autocratic tsar is not identical with the government in the eyes of the people, and the [government] is responsible for any policy harmful to Orthodoxy, autocracy, and the Russian people."22 In this way, the bureaucracy and various "internal and external enemies" were to pay for mistakes.

However , sometimes the extremists, or, as they were sometimes called, right-wing revolutionaries, with their disobedient populist rhetoric could cast even the Sovereign in a negative light. As an activist of the Orel SRN's cell, K. S. Krasil'nikov published the populist brochure "For the Faith, Tsar and

17. Ibid., 77-78.

18. Rogger, Jewish Policies and Right Wing Politics in Imperial Russia, 224-25.

19. N. A. Epanchin, Na sluzhbe trekh imperatorov. Vospominaniia (Moscow: Poligrafresury, 1996), 239.

20. Rogger, Jewish Policies and Right Wing Politics in Imperial Russia, 225.

21. L. A. Tikhomirov, Monarkhicheskaia gosudarstvennost' (Buenos Aires: Russkii Imp. Soiuz-orden, 1968), 244.

22. Polnyi sbornik platform vsekh russkikh politicheskikh partii (1906), 152. 
Fatherland" (Moscow 1906) in which he claimed that in 1905 "the tsar-father ... was fully in the hands of the powerful impudent beast, who imprisoned the tsar" and forced him "to sign his satanic fabrications" including the Manifesto of October 17. By "impudent beast", "cunning official," and Jewish agent Krasil'nikov was of course referring to Count Witte; while the feebleminded tsar-father was naturally Nicholas II. The brochure was confiscated as anti-governmental propaganda and the authorities initiated a criminal prosecution. Like many genuine revolutionaries Krasil'nikov went into hiding and stayed concealed until 1909 when he was arrested in his native city of Orel and finally imprisoned. ${ }^{23}$

There was another reason why Black Hundreds' attacks against the government could backfire. The authority of the state was not embodied by bureaucrats alone but primarily by Nicholas II. The failure of the authorities' prestige undermined the position of the monarch and hence the position of the monarchists too and strengthened political opposition to the latter. In this sense the autocrat and the parties of the supporters of autocracy were bound by an enduring thread. This is why right-wingers considering the political innocence of Nicholas II were distressed and felt that under such an indifferent monarch the monarchists would play an insignificant role. The right-wing Kievan professor Y. A. Kulakovskii wrote to his colleague A. I. Sobolevskii in Moscow in a spirit of typically Russian helpless gloom: "I have no hope for the monarchist parties: to have power they need the genuine Monarch, but we have instead a kind of miserable blancmange."24

In tsarist Russia, monarchist parties were in an extremely ambiguous, clumsy, and contradictory position. While calling for obedience to each word of the autocrat and pretending to show to all an example of loyalty and humble obedience, party activists on the Right struggled to play the role of independent politicians trying to underscore their independence and even critical attitude towards the government and local authorities. Although their monarch was the head of the state, possessing enormous power, the ideology of the Black Hundred movement contained a sharp dissatisfaction with political reality. The tsarist regime always thought that it was for the better to keep people out of politics; in full contradiction of this fundamental tradition of autocratic administration, "new wave" autocratic apologists widely appealed to the people to join the ranks of their political parties. Finally, the nationalist foundation of right-wing politics could hardly be a factor of conservative restraint in imperial Russia, insofar as it not only aroused much inter-ethnic

23. Za Veru, Tsaria i Otechestvo (Moscow, 1906), 17-18; A. V. Shevtsov, Izdatel'skaia deiatel'nost' russkikh nesotsialisticheskikh partii nachala $X X$ veka (St. Petersburg: Rossiiskaia Natsional'naia Biblioteka, 1997), 190.

24. Shevtsov, Izdatel'skaia deiatel'nost' russkikh . . , 26. 
friction but also called for a critical review of the entire past imperial practice. ${ }^{25}$ The idea from the SRN program (Osnovopolozheniia) - that "Russian sovereigns, beginning with Peter I, although they continued to call themselves autocrats, but this autocracy already was not Orthodox-Russian but rather closer to West-European absolutism" - cast a shadow of suspicion across all predecessors of Nicholas II beginning from the eighteenth century, if not on him too.

In particular, many Rightists were critical towards past emperors' nationalities policies, which in their opinion had led to the current crisis in the empire. For example, Markov came forward as the right-wing orator on the Finnish question. He noted a fact truly unique in the world history of imperial policy: when the Russian tsar Alexander I granted Finland a constitution "... and quite liberal, at the same time his very native Russian subjects were still slaves, his Russian people were sold in bazaars. ..." And under Alexander the Liberator authorities acted, according to Markov, "in the service of Finnish longings." ${ }^{26}$ For this disrespect to imperial authority the monarchists should have lost the right to speak, as Pavel Miliukov could not fail to notice, believing that speaker Markov insolently accused the sovereigns Alexander I and Alexander $\mathrm{II}^{27}$ Markov's economic analysis supporting the conclusion that "to this very day Finland lives entirely on Russian money, on the means of the Russian people," was already a slight to the reigning sovereign. ${ }^{28}$ Purishkevich, also critically inclined to the history and contemporary condition of the Finnish question, gave a clumsy explanation of the concessions given by Nicholas II to the Finnish constitution in the Manifesto of October 22, 1905. Nicholas II, following the logic of Purishkevich, signed the document because of his naivety if not insanity, insofar as this manifesto was "slipped under and given" to him, and no one could advise the tsar not to issue the manifesto, as "the imperial government knew nothing about its existence."29 Despite Purishkevich's best efforts, his criticism still had a rather provocative character.

The conservative wing of the Right never overcame one fundamental contradiction between two points: the principle of an absolutism requiring that people unquestioningly follow the prescriptions of the authorities; and their party activities, when the "people" organised in right-wing parties

25. Andreas Kappeler emphasised the incompatibility of Russian nationalism and the tsarist state in his Russland als Vielvoerkerreich. Entstehung. Geschichte. Zerfall (Munich: Beck, $1992)$, ch. 6 , pt. 5 .

26. Gosudarstvennaia Duma. Tretii sozyv, stenograficheskie otchety, sessiia 1, chast' 3 , zasedanie 64, columns 370-71.

27. Ibid., column 427.

28. Bbid., column 372 .

29. Ibid., zasedanie 66, column 695 . 
expressed their attitudes towards political events, up to and including the criticism of the autocratic head of the state. Count A. A. Bobrinskii, chairman of the Council of the United Nobility, an influential gentry organisation, ${ }^{30}$ wrote on November 22, 1915 to the former Minister of Justice I. G. Shcheglovitov (who had been persuaded by pravye to chair the United Rightwing Congress which was going on in Petrograd): "My objections are based on the consideration that the congress of monarchists represents, shall I say, a street, a pravaia street - but it's still a crowd. ... With this make-up of the congress we must be extremely careful about everything concerning the Supreme Authority. It appears to me that our current resolutions grate against this iron caution. ..." The monarchists' congress, as any political assembly would do, adopted resolutions on different political questions, including ministerial appointments. "All these are subjects," continued Bobrinskii, "about which it is entirely appropriate for members of the State Council to deliberate and even to make statements. These statements would never be known to the public. But the street, even the Rightist one, should not give instructions to the sovereign or even criticise his actions."31 K. P. Pobedonostsev and other self-respecting conservatives would have fully agreed with Bobrinskii's opinion.

Especially as the "street" organized somehow into the Union of Russian People, it was not fully convinced, despite their leaders' best efforts, that the tsar was always above suspicion, as documents shedding light on the internal situation in SRN demonstrate. Rank and file Unionists ventured (like the conspiratorial conservatives in salons) to voice their annoyance with the tsar. First of all they were dissatisfied with the marginal role given to monarchist parties in the monarchical state, especially after the revolution of $1905 \mathrm{had}$ been put down. One provincial member of the SRN complained to Dubrovin, "If [we serve] the Tsar, then where is he, this our Tsar? Why is he doing nothing when His best servants are being abused - for example, you. And we are kicked around again and again like dogs. ..."32 They wanted themselves to take domineering posts in the state but membership of the SRN helped only a very few to gain promotion. ${ }^{33}$ After 1907 the Union was in a state of disarray, but the tsar did nothing to strengthen the SRN's role.

30. See Geoffrey Hosking, Roberta Thompson Manning, "What Was the United Nobility," in The Politics of Rural Russia. 1905-1914, ed. L. Haimson (Bloomington and London: Indiana Univ. Press, 1979), 142-83.

31. Cited in A. la. Avrekh, Tsarizm nakanune sverzheniia (Moscow: Nauka,1989), 220-21.

32. GARF, f. 116, op. 1, d. 620,1.23(ob), 26 (ob).

33. Markov admitted that he knew of cases of promotions because of membership in the SRN [Padenie tsarskogo rezhima, 7 vols. (Moscow-Leningrad: Gosizdat, 1926), 6: 195]. But such a practice was rare. The SRN's odious reputation often had the reverse effect. (Shevtsov, Izdatel'skaia . ., 196). 
The rank and file of the Dubrovin wing of the SRN in particular criticized Nicholas II for his support of Stolypin's reform course. Stolypin's Westernizing reforms contradicted the patriarchal nationalist utopian ideals of the extreme Right. In 1909 the Black Hundreds reported that "the tsar is losing his supporters day by day." "The most loyal monarchists, seeing the total weakness of authority, are already beginning to accuse not only the First Minister. Even a year ago it was impossible to think about such an appraisal of the actions of the Head of the Monarchy." ${ }^{34}$ It sounded like a threat from those who by 1909 began to understand ministers in Russia could not administer without the tsar's approval. "Patriots" came "to the conclusion that the Government is inclined to play on the side of constitutionalism or perhaps such is the will of the reigning monarch," ${ }^{35}$

The Rasputin affair further alienated the supporters of the autocracy from the ruling autocrat. Society and especially monarchist circles were shocked that a scoundrel who took part in public debauchery had a long history of liaison with women, and who, according to popular gossip belonged to the sect of the khlysty (a sect known for group promiscuity), and had direct access and influence over that holiest of holies, the tsar.

Rasputin had been helped to make a fantastic path from his native selo, a village in the Tobolskii region, to Tsarskoe Selo by the extreme Right which was logical, considering their pretences to the role of the mediating link between the tsar and the "black millions." Father Ioann Vostorgov, the leader of the Moscow Rightists, met Rasputin when he still lived in Siberia and saw in the strange starets "a voice from the earth, from the old wooden plow, from the depths of the people." 36

However, Rasputin did not become an agent of extreme right-wing influence after his establishment at court. He did not appear to have any stable political views, if he had any at all; Peterburgskaia Gazeta once quoted Grigorii who had formulated his political credo in the following way: "Any politics is harmful. . . . Do you understand? All those Purishkevichs, Dubrovins make the devil happy, they serve him. One should serve people ... That is the politics." ${ }^{37}$ Anti-Semitism was not characteristic of Rasputin as it was of the Black Hundreds. ${ }^{38}$ In general he felt "the right wing are also fools," 39 al-

34. GARF, f. 116 , op. 1, d. 631, 1. 33 .

35. Ibid., I. 36.

36. See Alexander Etkind, Khlyst. Sekhi, literatura i revoliutsiia (Moscow: Novoe literatumoe obzrenie, 1998), 592; I. Leiberov, lu. Margolis, "Romanovy: Rasputin, ikh igry," Slovo, 6 (1993), 4.

37. Pravyie partii, 2: 751 .

38. Alexander Etkind, "Diskurs i revoliutsiia: Grigarii Rasputin," Revue des Etudes Slaves, 69, nos. 1-2 (1991), 244.

39. Padenie tsarskogo rezhima, 2: 58-59. 
though he helped Aleksandra Fedorovna compose answers to telegrams of monarchical groups ${ }^{40}$ as she perhaps thought he could show her the proper tone for interaction with common true-hearted subjects.

Ironically, it was the pravye that began the campaign against Rasputin. The first anti-Rasputin articles were published by Tikhomirov in 1910 in the leading conservative newspaper Moskovskie Vedomosti. ${ }^{41}$

At the end of 1911 the extreme Right in the Church attempted to end Rasputin's influence. His former friends, Black Hundred demagogue monk Iliodor and the extreme right-wing Bishop of Saratov Germogen, invited Rasputin to Germogen's residence in St. Petersburg where the two conducted Rasputin's "exposure," much to the latter's surprise. Having recounted Rasputin's sins, Bishop Germogen demanded Rasputin vow never to return to the tsar's palace. In his memoirs Father Georgii Shavel'skii, a reliable historical source, even wrote that lliodor and like-minded comrades attacked the resistant Siberian peasant and tried to castrate him (so as to end once and for all his debauchery), but Rasputin fought back and escaped. ${ }^{42}$ He then complained to the emperor; the extreme monarchists as a result suffered a terrible humiliation. Germogen was ordered to leave the capital immediately, lost his Saratov post, and was sent to the Zhirovitskii monastery, while Iliodor (whom even Stolypin could not touch because he enjoyed the tsar's sympathy) was exiled to the distant hermitage of the Vladimirskii diocese. ${ }^{43}$ This clearly demonstrated Rasputin's influence over the Church administration. Those suffering from this loudly protested through the media, exposing "the very harmful religious heretic and the spreader of the new khlyst teaching in Russia". After that the already widely known name of Rasputin became used as a symbol discrediting the monarchy among a wide strata of the population, seriously injuring the prestige of the tsar and the empress, and the Orthodox hierarchy, which now appeared unable to stand up against the influence of "dark forces."

Purishkevich was shocked. He shared his feelings with the Duma Chairman Rodzianko speaking "with horror and depression": "And the most terrible is that it seems to come from the very highness of the tsarist throne. One rogue, khlyst, dirty illiterate muzhik plays with our holy hierarchs." "If revolution comes - the Metropolitan Antonii Volynskii, the father of the Rightist

40. Perepiska Nikolaia i Aleksandry Romanovykh (Moscow: Gosizdat, 1923-27), 5: 164.

41. Firsov, Pravoslavnaia Tserkov'. ., 170.

42. Georgii Shavel'skii, Vospominaniia poslednego protopresvitera russkoi armii i flota (New York: Izd-vo Chekhova, 1954), 1: 59. For an explanation of the plot, see Etkind, "Diskurs $i$ revoliutsiia," 245

43. Firsov, Pravoslavnaia Tserkov' . ., 217-22.

44. Rodzianko, Krushenie imperii (Leningrad: Priboi, 1927), 27-28. 
movement in the southwestern regions, warned - it will be a punishment for the preference of khlystovshchina to Orthodoxy."

However it turned out that the Rightists were unable to adopt a unanimous view on Rasputin, as previously on many other questions. The main problem was a necessity to oppose the Supreme will of the Tsar. Unlike Tikhomitov or Purishkevich, some of the Rightists could not find courage to do so. Dubrovin, as far as we know, was on good terms with Rasputin. ${ }^{46}$ There were those who joined the admirers of starets, as the editor of the right-wing Kolokol V. M. Skvortsov did. Nikol'skii, who so much wanted finally to satisfy his ambition to take a powerful position, tried to use Rasputin's influence for the advancement of his own career. ${ }^{47}$ By that time, Nikol'skii had conflicts with almost all of his former comrades and in 1912 he took a modest post as the secretary of General Bogdanovich. The General, who was 82 , shortly before his death in 1914 sent a letter to Nicholas II urgently asking him to keep Rasputin away from the throne. Thus, disagreements were seen even among the close collaborators. Yet the majority of the Right shared Purishkevich's feelings.

For revolutionaries this situation made Rasputin an incredible find. However it was not true that, as some Rightists believed, Rasputin was "sent by internationalists. ${ }^{48}$ In fact, the Black Hundreds contributed much more to the appearance of this figure that became fatal for Nicholas II.

In the last years of the empire, Rasputin's role had grown thanks to a "Rasputin clique" of incompetents appointed to high government and Church positions. This only highlighted the corruption of the regime and strengthened popular hatred. The right wing again played an important role in exposing Rasputin's scandals. Pravye in the Duma, particularly Purishkevich, whose voice was heard nationwide, exposed the "dark forces" settled near the throne. One could only be amazed that all this came from the mouths of people appearing on the political scene to confirm their loyalty to the tsar. In these circles a plan arose to get rid of Rasputin, ${ }^{49}$ and while the more moderate Shul'gin was not in favor of the murder, ${ }^{50}$ Purishkevich with aristocratic

45. The letter of the Metropolitan Antonii to the Bishop of Ufa Andrei, November 20, 1916. ["Petepiska pravykh i drugie materialy ob ikh deiatel'nosti v 1914-1917 gg.," Voprosy istorii., 8, (1996), 82].

46. Padenie tsarskogo rezhima, 4: 282, 289.

47. Pravye partii, 2: 751.

48. Bakhmeteff Archive (BA), V. Vostokov's Collection, "Tochnye dannye k posluzhnomu spisku mitrofornogo protoiercia Vladimira Vostokova," 1. 6.

49. Ibid., 364.

50. V. V. Shul'gin, Dni. 1920 (Moscow: Sovremennik, 1990), 154. 
plotters killed this most influential peasant of the empire on December 17, $1916 .{ }^{51}$

Pravye politics led towards a dead end. The principle of loyalty to the autocracy became incompatible with independent politics and the principle of fidelity to a nation suffering in a world war because of the incompetence and irresponsibility of Rasputin's protégés, appointed by the will of the tsar.

The history of Rasputin illuminates the traditional patriarchal outlook of Nicholas II regarding the Russian political world. Caught up in family concerns, he ignored the appeals including those of his right-wing allies, a source of political support. It remained his belief that a Russian tsar was not obliged to heed the voice of parties.

By 1917 , when the whole of political society had become extremely irritated with the tsar, the majority in the Right was also largely dissatisfied. A significant group of moderate pravye in the Duma, "progressive Nationalists," where Shul'gin played a major role, had entered the Progressive Bloc in 1915 and thus joined the "opposition." To a great surprise, even the Union of Archangel Michael moved the same way. After Purishkevich gave critical speeches in the Duma, the SRN accused him of betraying monarchism and of trying to be popular - "washing dirty linen in public" - rather than modestly presenting a loyal petition (chelobitnaia) to the tsar. ${ }^{52}$ In answer to this, the main chamber of the SMA sent out a circular to all its local organizations explaining that the idea of a monarchist's loyalty was publicly to unmask all discord for the cause of saving Russia: ". . . one needs to serve the tsar with the truth, to tell him boldly about people who do not deserve his trust and bring harm to the state." 53 The Nationalist V. A. Bobrinskii in his Duma speech in November 1916, where he criticised the minister of Interior A. D. Protopopov, explained his understanding of loyalty to a higher authority in the following way: "I understand monarchism differently than Aleksandr Dmitrievich [Protopopov] does. He speaks and often emphasizes that he is a blind executor of the Sovereign's will. ... The Sovereign needs faithful people, not lackeys, and monarchists need to remember this." 54 Such an understanding of their duty, when the tsar's "faithful people" practically rose up in opposition to him in the name of the good of society, became more and more widespread among monarchists.

51. Most likely the account of this was spruced up in V. M. Purishkevich, Ubiistvo Rasputina (Paris, n.d.). 2.

52. Tsentral'nyi Gosudarstvennyi Arkhiv Ukrainy. (TsGIA Ukraine), f. 301, op. 2, d. 203, 1.

53. L. M. Spirin, Krushenie pomeshchich'ikh i burzhuaznykh partii v Rossii (Moscow: Mysl', 1977), 212.

54. Gosudarstvennaia Duma. Stenograficheskie otchety. IV sozyv. Sessiia 5 (Petrograd, 1917), col. 295-97. 
Between those extreme Rightists led by Markov who still remained loyal to the regime, the majority, according to Purishkevich, sympathised with the opposition and only party discipline of their Duma fraction forced them to refrain from open criticism. ${ }^{55}$

Markov's caustic comment that the Progressive Bloc was "yellow," was proudly warded off by Shul'gin, who said that the Bloc was "Tricolor," white-blue-red, the colors of the Russian national flag. As Shul'gin's biographer noted, he cared more for saving the monarchy rather than Nicholas II; but he was yet more concerned about saving Russia than the monarchy. ${ }^{56}$ This evolution obviously reflected the development of modern nationalism in Russia, when traditional absolute loyalty to the monarch was replaced by loyalty to the nation as an impersonal Fatherland. The results of the cultural innovations of Peter the Great, who had opened the way for European influences, ${ }^{57}$ suddenly turned against his descendant after two hundred years. Shul'gin's colleague Men'shikov, discussing the reasons for the disasters of his Fatherland in the aftermath of the Bolshevik coup, concluded that it was the centuries-old misfortune of Russians that they were slaves of a "German dynasty," "and besides a degenerate and untalented one."

For "progressive nationalists," if we can use this term for Russian patriotic society that supported the Progressive Bloc, it was clear that Nicholas II and Aleksandra Fedorovna, having lost almost all their allies, were leading the country towards a catastrophe. The Kadet V. V. Lashkevich on the eve of the revolution described the hostility of the leader of the Progressive Nationalists to the tsar: "Shul'gin, right-winger, called . . . the tsar the opponent of everything that country needs as much as air to breathe." 59 In his diary, Purishkevich called Aleksandra Fedorovna "the evil genius of Russia and the tsar" before the revolution. ${ }^{60} \mathrm{Nikol}$ 'skii, freed from harboring any illusions by the 1905 events, was now absolutely disillusioned and convinced that "the degeneration of the dynasty is so clear and so beyond hope that the situation is hopeless."

55. V. M. Purishkevich, Dnevnik: Kak ia ubil Rasputina (Moscow: Sovetskii pisatel', 1990), 21-22.

56. Bruce Adams, "The Extraordinary Career of Vasilii Shul'gin," Revolutionary Russia, 5, no. 2 (Dec. 1992), 198.

57. Liah Greenfeld, Nationalism: Five Roads to Modernity (Cambridge, MA: Harvard Univ. Press, 1995), 192-93.

58. Rossiiskii Arkhiv, Istoriia otechestva v svidetel'stvakh idokumentakh XVIII-XX vekov, 12 vols. (Moscow: Studiia Trite, 1991-99), 4: 11-12.

59. Cit. in Kotsubinskii, Russkii natsionalizm v nachale XX stoletiia, 280.

60. Purishkevich, Dnevnik, 41, 46.

61. Cited in B. V. Anan'ich, R. Sh. Ganelin, eds., Vlast' $i$ reformy. Ot samoderzhaviia $k$ Sovetskoi Rossii (St. Petersburg: D. Bulanin, 1996), 615. 
News was also coming from the provincial Black Hundreds' rank and file of the complete collapse of the tsar's prestige and even of revolutionary ferment. "It is even difficult to say who is more inclined to revolution: the right-wing lower classes or the left-wing intelligentsia circles," wrote Black Hundred professor A. S. Viazigin from Khar'kov on November 30, 1915. In a letter to Zamyslovskii in December of the same year, the professor warned that the idea of overthrowing the tsar "is enjoying significant success even in right-wing circles." 62

In those Black Hundred strata that were susceptible to various conspiracy theories, a corresponding set of explanations for current events was born. According to the report of right-winger father Vostokov, Feofan, Archbishop of Poltava, interpreted the reasons for the crisis the following way: "After His Coronation in 1896 the Sovereign and Consort paid a coronation visit to the French President in Paris. And here, the devil's cunning representatives of the Jew-Masons, direct enemies of Christianity and especially of Holy Orthodox Rus', created it in the grounds of the Elysee; they seduced the Tsar into joining a Masonic lodge. . . . Great Russia is slipping down into the abyss of satanism. ..."63

It is not surprising that in February 1917 the tsar's abdication led to unanimous rejoicing. "Who would stand with him?," asked Shul'gin, shaken by the events. "He has no one, no one. . .."64

The downfall of the monarchy led immediately to the breakup of rightwing parties. The history of this strange phenomenon - small fragmentary monarchist parties in a country where in theory everyone was supposed to be absolutely loyal to their autocrat - was now over. Regardless of all undercurrents and, especially by 1917 , noticeable internal opposition to Nicholas II, ideologically right-wing groups were so tightly linked to the monarchy that the fall of the latter led to their immediate liquidation. With an iron grip Monarchism hampered the development of a conception (natural for nationalist movements) of a populist national leader instead of a venerated traditional dynastic tsar.

Still, these tendencies in pre-revolutionary Russian nationalism had their place. The VNS celebrated Stolypin as a leader of Russian nationalism in many ways, ${ }^{65}$ and Shul'gin expressed the opinion that "in certain circumstances" Stolypin would be ideal to sit on the tsarist throne. ${ }^{66}$ Among the Black Hundreds - who ideologically were closer to fascism by their crude

62. Cited in Avrekh, Tsarizm nakanune sverzheniia, 225.

63. BA, Vostokov's Collection, 'Na Severnom Kavkaze i na Kubani s Donom.," 1. 10.

64. V. V. Shul'gin, Gody. Dni. 1920 (Moscow: Novosti, 1990), 459.

65. Kotsubinskii, Russkii natsionalizm v nachale XX stoletiia, 488-502.

66. V. V. Shul'gin, "Glavy is knigi Gody," Istoriia SSSR , 6 (1966), 77. 
identification of friends and enemies through national identity and populist demagoguery - scholars noticed the appearance of the leader cult of the Führerprinzip type. ${ }^{67}$

Yet the particularly auxiliary role that the right-wing parties played in the autocratic regime of Nicholas II did not allow anyone to arise from their numbers who could pretend to the position of national leader. One of the main reasons that Russia did not anticipate Italian history (where the Duce pushed the monarch down to a secondary position) was the enormous authority of the Russian tsar, looking down from the heights of the throne upon the small bustle of right-wing leaders trying to obtain his good graces. ${ }^{68}$

After the civil war in exile, where the Black Hundreds were liberated from the grip of the tsarist order, it grew quite naturally into fascism. ${ }^{69}$ However, in Russia until 1917 such a development was blocked by the reign of Nicholas II, who did not give nationalists the chance to lay claim to that authority that the tsar himself jealously guarded. "The revolt against the tsarist authorities for the sake of the power of the tsar was impossible - Markov wrote as an émigré. - We had to turn down aggressive state building activity (or fascism) and deeply retreat to keep the holy banners of the autocracy." ${ }^{\text {"T }}$ The rule was confirmed whereby an authoritarian regime restrains the possible appearance of nationalist or populist dictatorship that receives its chance in a crisis of liberal democracy.

The striking weakness of monarchist doctrine was an issue which became critical under Nicholas II: what a good monarchist should do if "providence gave a wrong card," and authority was passed to a tsar who was harmful to the fatherland. An unlimited autocrat - in the Black Hundreds' preferred type, unrestricted even by those laws granted by him or his predecessors looked frightening for the country if he set an incorrect political course. Alas, apart from hoping for good fortune, monarchists could not resolve this dilemma. In his book (published in emigration at the end of the civil war), Shul'gin planned out in his imagination that the throne after a restoration

67. D. I. Raskin, "Ideologiia russkogo pravogo radikalizma v kontse XIX-nachale XX vv.," in Natsional'naia pravaia prezhde i teper': Istoriko-sotsiologicheskie ocherki, chast'1 (St. Petersburg: In-t sotsiologii RAN, 1992), 31-33.

68. Rogger showed the helplessness of fascism in tsarist Russia: Rogger, Jewish Policies and Right Wing Politics in Imperial Russia, 212-32.

69. See John Stephan, The Russian Fascists: Tragedy and Farce in Exile, 1925-1945 (London: Hamilton, 1978).

70. N. E. Markov, Voiny temnykh sil (Paris: “Doloi zlo," 1928), 1: 137. 
would be occupied by a tsar with the traits of Peter Stolypin. However there was no guarantee that things would turn out this way, that instead of the alter ego of Stolypin another fatal figure would not appear on the throne and lead the country to a new catastrophe. Shul'gin, one of the more broad-thinking authors among the Right, could not deliver any such guarantee.

Autocracy seemed to be good for the country, the population of which observed political silence. However, Russian society, part of which was to the Right, had outgrown the bounds of absolutism and was yearning to play a more political role. An increasing number of subjects considered it appropriate to have their own independent opinions thanks to the spread of education and European culture.

The number of advisers to the tsar was growing quickly, and were so active during the 1905 crisis that they even formed their own political parties in order to influence the tsat more effectively. In spite of theoretical objections even the Black Hundreds were forced to proceed at the same pace of social development. Indeed, those they drew into political debates on the Supreme Authority were mainly the ones whom they could easily impress - the uneducated and backward strata of the population from the national hinterlands. They deliberately rejected a formal bureaucratic absolutism that held the population in silent obedience, in favor of a mythical tradition of pre-Petrine Rus', when by their imagination the voice of the Russian people was heard by the authorities and made its way to the tsar unhindered. However, bringing this patriarchal utopia to life was clearly not in the power of any ruler. Between the right-wing radicals and the emperor conflict would inevitably arise, reflecting the contradiction between the radical utopianists and the traditional ruler.

The fate of Russian tsars in the previous century, who had invariably inspired dissatisfaction from political activists of various stripes, had been tragic. Paul I was strangled by plotters; the death of Alexander I led to the Decembrist uprising. Nicholas I died, stunned by the drawbacks of the Crimean War. A terrorist's bomb killed Alexander II. Alexander III was able to die a natural death largely thanks to the fact that he brought police control over society to a breaking point.

Even had a political genius been sitting on the throne at the time of Nicholas II, he would have made many unhappy. Incompetence of Nicholas II only stimulated the crisis of the already ineffective system. Sympathetic to the nationalists, Nicholas II expressed favor towards right-wing politicians, in part unconsciously trying to secure social support for his regime. The result of such attempts was the catastrophe of the February Revolution, which revealed the disillusionment in Nicholas II felt by a vast majority of his subjects, including those who appeared on the political scene with the goal of saving autocracy and the national foundations. 